\begin{tabular}{|c|c|c|c|c|c|c|}
\hline \multirow{4}{*}{ Impact Factor: } & ISRA (India) & $=3.117$ & SIS (USA) & $=0.912$ & ICV (Poland) & $=6.630$ \\
\hline & ISI (Dubai, UAE & $=0.829$ & РИНЦ (Russia) & $=0.156$ & PIF (India) & $=1.940$ \\
\hline & GIF (Australia) & $=0.564$ & ESJI (KZ) & $=8.716$ & IBI (India) & $=4.260$ \\
\hline & JIF & $=1.500$ & SJIF (Morocco & $=5.667$ & OAJI (USA) & $=0.350$ \\
\hline
\end{tabular}

\begin{tabular}{|c|c|}
\hline $\begin{array}{l}\text { SOI: } \underline{1.1 / \mathrm{TA}} \\
\text { International Sc } \\
\text { Theoretical \& }\end{array}$ & $\begin{array}{l}\frac{S}{\text { DOI: }} 10.15863 / \mathrm{TAS} \\
\text { ientific Journal } \\
\text { pplied Science }\end{array}$ \\
\hline p-ISSN: 2308-4944 (print) & e-ISSN: 2409-0085 (online) \\
\hline Year: 2019 Issue: 03 & Volume: 71 \\
\hline Published: 29.03 .2019 & http://T-Science.org \\
\hline
\end{tabular}

SECTION 31. Economic research, finance, innovation, risk management.
QR - Issue

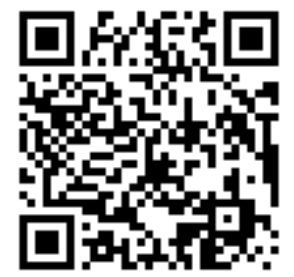

Sherali Sharipovich Jurayev Senior teacher, Namangan engineering-building institute

\title{
ANALYSE OF THE PERMEABILITY OF BENTONITE AND SAND IN SOIL STRUCTURES
}

\begin{abstract}
Language: English Theoretical \& Applied Science, 03 (71), 437-440.

\section{Introduction}

In the practice of hydro technical construction, anti-filtration devices which made of clay soils (ponures, screens, cores, etc.) are widespread. When constructing them, it is very important to correctly assess the permeability of the soil. The overestimation of this value leads to excesses in the construction and unproductive expenditures of material resources, and an understatement leads to higher filtration losses $[1,2]$.

Bentonite clay - is one of the valuable fossil materials that has found it's widely application in various fields of human activity. Its other name is cloth clay, which is used for degreasing cloth. In modern industry, bentonite clay is used mainly in metallurgy to form iron ore pellets and to make molding sands. Equally important is the use of bentonite clay in the preparation of drilling and mortar, cleaning products for petroleum products, and also as a raw material for the production of heat and waterproofing materials.
\end{abstract}

Abstract: In this article discusses the results of analysis of permeability of soils. In the practice of hydro technical construction, widespread impervious devices made of clay soils. When constructing them, it is very important to correctly assess the permeability of the soil. Based on experimental studies, the filtration coefficient of bentonit was determined and recommendations and practical use were developed.

Key words: permeability, bentonite, filtration coefficient, pressure, flow rate, soil, sand, water, suffusion.

Citation: Jurayev, S. S. (2019). Analyse of the permeability of bentonite and sand in soil structures. ISJ

Soi: http://s-o-i.org/1.1/TAS-03-71-35 Doi: crossef https://dx.doi.org/10.15863/TAS.2019.03.71.35

\section{Literature review}

Research on textile features were investigated in works of local scientists [7-10]. Conducting these analysis is necessary, since there is still no clear indication in the literature about the most appropriate method for determining the filtration coefficient of low-permeable bentonite. Moreover, some authors even doubt about the possibility of determining it directly, in connection with which they recommend to study this important soil characteristic indirectly according to other analyze methods [3].

Wastewater treatment of rainwater and industrial-rainwater drainage is usually carried out either at "independent" sewage treatment plants or at facilities ensuring their joint treatment with domestic or industrial wastewater.

Constructions for the joint treatment of these waste waters are found mainly in the cities of Europe and the USA [-3]. In this case, two process lines are arranged: on the first, biological treatment of the mixture of household waste and the estimated volume of rainwater is carried out, and on the second, accumulation, mechanical and physico-chemical treatment of the above-calculated volume of rainfall water is carried out.

Preliminary mechanical purification of rainwater wastewater is carried out with the help of gratings of various designs, as well as vortex and whirlpool separators [4].

Physical and chemical cleaning is carried out, as a rule, in two steps.

At the first stage, the wastewater is treated with coagulant (salts, iron or aluminum) and flocculant, followed by clarification in thin-layer horizontal or radial clarifiers, as a rule, with a mechanical type flotation chamber. To intensify the process of settling, in addition to the reagent treatment, recirculation of sludge and sand microparticles obtained from sludge 


\begin{tabular}{|c|c|c|c|c|c|c|}
\hline \multirow{4}{*}{ Impact Factor: } & ISRA (India) & $=3.117$ & SIS (USA) & $=0.912$ & ICV (Poland) & $=6.630$ \\
\hline & ISI (Dubai, UAE & $=0.829$ & РИНЦ (Russia & $=0.156$ & PIF (India) & $=1.940$ \\
\hline & GIF (Australia) & $=0.564$ & ESJI (KZ) & $=8.716$ & IBI (India) & $=4.260$ \\
\hline & JIF & $=1.500$ & SJIF (Morocco & $=5.667$ & OAJI (USA) & $=0.350$ \\
\hline
\end{tabular}

in hydrocyclones is used [5]. Often at the first stage, flotation units are used instead of settling tanks [6].

At the second stage, either single-layer filters with sand loading or double-layer filters with sand and anthracite are used for water purification [6, 7]. Disinfection of purified water is carried out with chlorine-containing reagents, ozone, ultraviolet or peroxoacetic acid [6].

For local treatment of rainwater from relatively small catchment areas in the USA, biotechnological methods are widely used, based on the use of artificial structures with plants (grass, shrubs, trees, coniferous vegetation, etc.). For example, along the perimeter of parking lots, plant anti-erosion strips are laid. Along the freeways arrange canals with vegetation. In order to purify rainwater from parking lots and rooftops, biological sites are used for underground filtration. In addition, infiltration trenches, sand and gravel filters and biological ponds are widely used [8].

\section{Analysis and results}

For the treatment of large volumes of rainfall wastewater from undeveloped areas, which are the main source of feed for rivers or lakes, for example, in Florida (USA), ponds are being built. They are special hydraulic structures designed to stay in them water for 12-24 hours. In order to reduce the concentration of suspended solids, heavy metal compounds, phosphorus, nitrogen and reduce BOD total. wastewater is preliminarily coagulated with aluminum sulfate [9]. The sediment formed in the settling basins is either dumped into the domestic sewage network, or subjected to treatment with highmolecular flocculant, and then dehydrated using the drainage method at the sites. Dehydrated sludge is used as a placeholder for land restoration.

Fractional analysis of bentonite is refers to clay rocks, since the content of particles with diameter $\mathrm{d}$ $<0.005 \mathrm{~mm}$ is more than $30 \%$.

The article deals with the analyse of the permeability of bentonite of a broken structure, taking into account some additives that are recommended for reducing the permeability of the soil used as an impervious material. In modern literature and regulatory documents, a significant number of various devices have been proposed to determine the filtration coefficient $[3,4]$. However, their application in the study of clay soils in the field requires some features. To this end, we have developed a device design for analysing bentonite. The instrument for determining the filtration coefficient of bentonite includes the following elements: Compression filtration device, which allows conducting analysis close to natural conditions. The composition of the compressionfiltration device should include: mesh with filter, providing free flow of water to the sample and its withdrawal; roof on the device; choke connector; Libra; stopwatch; thermometer; scales and others.

In the implementation of field studies, based on the design of the available instruments, new installations were created to determine the filtration coefficient of bentonite [5,6]. According to GOST 25584-90, the preasure on the stamp should be no more than $0.0025 \mathrm{MPa}$ or $2.5 \mathrm{kPa}$ in order to prevent soil swelling. Taking this factor into account, a soil from local sand was installed in a cylindrical chamber $(\mathrm{d}=150 \mathrm{~mm})$. The density of the soil was $\beta=1.42 \mathrm{~g}$ $/ \mathrm{cm}^{3}$

According to preliminary calculations, it was established that the flow of water through bentonite is $Q<10^{-3} \mathrm{~cm}^{3} / \mathrm{s}$.

According to GOST 23278-78, permeability is determined by the formula:

$$
C=\frac{Q \mu \ell}{\Delta P F}
$$

$C$ - permeability coefficient;

$\ell$ - the length of the filtration path, the thickness of bentonite, $\mathrm{cm}$;

$Q$ - volumetric flow rate, $\mathrm{sm}^{3} / \mathrm{s}$;

$\Delta P$ - pressure drop, $\mathrm{kgf} / \mathrm{sm}^{2} ;$

$F$ - cross-sectional area,

$\mu$ - coefficient of dynamic viscosity;

Then the filtration coefficient is determined by the formula:

$$
k=a C \frac{\gamma}{\mu} \quad \text { or } \quad k=\frac{Q \ell}{\Delta H F}
$$

where: $a$ - dimensionality factor in $k \mathrm{sm} / \mathrm{s} ; \gamma$ specific weight of water, $\mathrm{kgf} / \mathrm{sm}^{3}$.

Inside the cylindrical device, bentonite is compacted in $4.5 \mathrm{sm}$ thick dissolved water. The density of the soil was $1600 \mathrm{~kg} / \mathrm{m}^{3}$. Water was supplied from a pressure tank with a pressure of 130 $\mathrm{sm}$. The results of the study are presented in table 1 . 


\begin{tabular}{|c|c|c|c|c|c|c|}
\hline \multirow{4}{*}{ Impact Factor: } & ISRA (India) & $=\mathbf{3 . 1 1 7}$ & SIS (USA) & $=0.912$ & ICV (Poland) & $=6.630$ \\
\hline & ISI (Dubai, UAE & $=0.829$ & РИНЦ (Russia & $=0.156$ & PIF (India) & $=1.940$ \\
\hline & GIF (Australia) & $=0.564$ & ESJI (KZ) & $=8.716$ & IBI (India) & $=4.260$ \\
\hline & JIF & $=1.500$ & SJIF (Morocce & $=5.667$ & OAJI (USA) & $=0.350$ \\
\hline
\end{tabular}

Table 1. Bentonite filtration coefficient.

\begin{tabular}{|c|c|c|c|c|c|c|}
\hline № & $\mathrm{W}, \mathrm{sM}^{3}$ & $\mathrm{~L}, \mathrm{~cm}$ & $\mathrm{H}, \mathrm{sm}$ & $\mathrm{F}, \mathrm{sM}^{2}$ & $\mathrm{~T}$, hour & $\mathrm{k}, \mathrm{sm} / \mathrm{s}$ \\
\hline 1 & 200 & 4,5 & 130 & 314 & 237 & $0,25 * 10^{-7}$ \\
\hline 2 & 175 & 4,5 & 130 & 314 & 221 & $0,8 * 10^{-7}$ \\
\hline 3 & 120 & 4,5 & 130 & 314 & 182 & $0,13 * 10^{-6}$ \\
\hline 4 & 160 & 4,5 & 130 & 314 & 204 & $0,9 * 10^{-7}$ \\
\hline 5 & 140 & 4,5 & 130 & 314 & 190 & $0,1 * 10^{-6}$ \\
\hline 6 & 80 & 4,5 & 130 & 314 & 162 & $0,2 * 10^{-6}$ \\
\hline
\end{tabular}

Source: author`s elaboration.

To assess the permeability of bentonite, it is necessary to determine the filtration coefficient of the sand which the dam body of the reservoir is built. To determine the filtration coefficient of sands, we use the Kamensky device in field conditions[5].

The filtration coefficient is determined by the formula:

$$
K=\frac{l}{T} \varphi\left(\frac{S}{h_{0}}\right)
$$

where: $h_{0}$ - initial pressure;

$S$ - level drop;

$l$ - the length of the filtration path (the height of the column of sand in the tube). $T$ - filtration time;

Temperature correction to the value of the filtration coefficient:

$$
\tau=0,7+0,03 \cdot t
$$

The results of the experiment are summarized in Table 2.

Table 2. Sand filtration coefficient.

\begin{tabular}{|c|c|c|c|c|c|c|c|c|c|}
\hline Soil & $\begin{array}{c}h_{0}, \\
\mathbf{s m}\end{array}$ & $\boldsymbol{S}, \boldsymbol{s m}$ & $\boldsymbol{T}, \boldsymbol{c}$ & $\varphi\left(\frac{S}{h_{0}}\right)$ & $l, \mathbf{s m}$ & $\boldsymbol{K}, \boldsymbol{s m} / \mathbf{s}$ & $\boldsymbol{t}$ & $\tau$ & $K_{10}=\frac{K}{\tau}$ \\
\hline Sand & 86 & 35,3 & 540 & 0,41 & 15 & 0,014 & 18 & 1,24 & 0,011 \\
\hline Sand & 39 & 11,5 & 300 & 0,346 & 15 & 0,017 & 18 & 1,24 & 0,0137 \\
\hline Sand & 28,5 & 9 & 300 & 0,315 & 15 & 0,015 & 18 & 1,24 & 0,0121 \\
\hline Sand & 50,5 & 13,8 & 300 & 0,273 & 15 & 0,0136 & 18 & 1,24 & 0,011 \\
\hline
\end{tabular}

Source: author`s elaboration.

Based on the results of research about permeability of sand, the body of the dam and bentonite made the following conclusions:

- When testing bentonite clays in order to reduce the time to determine the filtration coefficient, it is necessary to create a large head.

- When determining the filtration coefficient of bentonite, the time factor is essential, i.e. the duration of the experiment.

- Determination of the filtration coefficient of bentonite samples with a broken structure should be carried out at high pressure gradients, which makes it possible to drastically reduce the duration of experiments, reduce the spread of experimental values and improve the accuracy of determination.

- According to research results, the value of the filtration coefficient is on average $0.4 * 10^{-7} \mathrm{sm} / \mathrm{s}$.

- According to the research results, the sand filtration coefficient of the dam body of the reservoir was established and the average value is $\mathrm{K}=0.015$ $\mathrm{sm} / \mathrm{s}$.

- It should be noted that the tests were carried out without taking into account chemical phenomena in the filtration process, nature of bentonite has not yet been fully studied. 


\begin{tabular}{|c|c|c|c|c|c|c|}
\hline \multirow{4}{*}{ Impact Factor: } & ISRA (India) & $=3.117$ & SIS (USA) & $=0.912$ & ICV (Poland) & $=6.630$ \\
\hline & ISI (Dubai, UAE & $=0.829$ & РИНЦ (Russia & $=0.156$ & PIF (India) & $=1.940$ \\
\hline & GIF (Australia) & $=0.564$ & ESJI (KZ) & $=8.716$ & IBI (India) & $=4.260$ \\
\hline & JIF & $=1.500$ & SJIF (Morocco & $=5.667$ & OAJI (USA) & $=0.350$ \\
\hline
\end{tabular}

- The tests did not take into account the phenomenon of suffusion, which occur during insufficient compaction of soils.

\section{Conclusion}

According to the results of studies of the water permeability of bentonite in the form of a powder, it was established that without creating a shell around bentonite, the phenomenon of mechanical suffusion is possible, which creates the risk of compromising the safety of a pressure hydraulic structure. Analysis of the results of laboratory studies showed that with an increase in the pressure of water from the pressure tank, the filtration of water through bentonite increases and the time of the experiment decreases, depending on the pressure. The tests did not take into account the phenomenon of mechanical suffusion, which occur during insufficient compaction of soils. As well as resistance to effects on bentonite, the presence of salts contained in water.

\section{References:}

1. (1998). GOST 25584-90. Soils. Laboratory methods for determining the filtration coefficient.

2. Zamaleev, Z. K., Posokhin, V. N., \& Chefanov, V. M. (2014). Fundamentals of hydraulics and heat engineering: a manual. (p.352). St. Petersburg: Lan.

3. Arifjanov, A., \& Juraev, S. (2018). Methods for studying filtration properties bentonites in hydraulic structures. (pp.271-273). Subscribe to the Fergana Valley report on the theme of "Fergana Valley" on October 27-28, 2018.

4. Sologaev, V. I. (2002). Filtration calculations and computer modeling in the protection against flooding in urban construction. Monograph. (p.416). Omsk: SibADI Publishing House.

5. Kolomensky, N. V. (1956). Engineering geology. Moscow: Gosgeoltehizdat.

6. Arifjanov, A., \& Jurayev, S. (2012). The value of bentonite in the study of the filtration process in hydraulic structures. FerPI scientific and technical journal, № 3, 14-17.

7. Tursunov, B. O. (2018). The world experience of the investment funds development and the prospects of their development in uzbekistan. (pp.152-155). v sbornike: nauchnye issledovaniya v sotsial"no-ekonomicheskom razvitii obshchestva Materialy II Mezhdunarodnoy nauchno-prakticheskoy konferentsii. 2018.

8. Tursunov, B. O., Krivyakin, K. S., \& Khakimov, konkurentosposobnosti produktsii tekstil"nykh predpriyatiy. Naukoviy visnik Polissya, № 2-2 (14), 71-77.

9. Kasymov, S. S., Tursunov, B. O., \& Karimov, B. A. (2017). Razvitie mezhotraslevykh struktur metodom klastera $v \quad$ integratsionnykh korporativnykh strukturakh khlopkovoy industrii. (pp.1309-1311). V sbornike: Nauchnoprakticheskie puti povysheniya ekologicheskoy ustoychivosti i sotsial'no-ekonomicheskoe obespechenie sel'skokhozyaystvennogo proizvodstva Materialy mezhdunarodnoy nauchno-prakticheskoy konferentsii, posvyashchennoy godu ekologii v Rossii. (Sostaviteli N.A. Shcherbakova, A.P. Seliverstova).

10. Yuldashev, N., \& Tursunov, B. (2018). Applying of artificial intelligence in the textile industry as factor of innovative development of the branch. Byulleten' nauki i praktiki, T. 4, № 4, 396-403.

11. Ibragimov, I. U., \& Tursunov, B. O. (2017). Enhancement the mechanism of analyzing of the methodological principles for the development and improvement of methods of assessment. Audit, № 4, 11-13.

12. Tursunov, B. O. (2017). Osnovnye napravleniya podderzhki malogo biznesa $\mathrm{v}$ uzbekistane $\mathrm{i}$ zarubezhnyy opyt razvitiya predprinimatel"stva. Audit, № 6, 34-38. 